\title{
Whole-Genome Amplification by Adaptor-Ligation PCR of Randomly Sheared Genomic DNA (PRSG)
}

\author{
Nona Arneson, Simon Hughes, Richard Houlston, and Susan Done
}

This protocol was adapted from "PCR-Based Whole Genome Amplification," Chapter 18, in PCR (eds. Hughes and Moody). Scion Publishing Ltd., Oxfordshire, UK, 2007.

\section{INTRODUCTION}

PCR-based whole-genome amplification (WGA) has the goal of generating microgram quantities of genome-representative DNA from picogram or nanogram amounts of starting material. This amplification should introduce little, or ideally no, representational bias. In contrast to other techniques for WGA, PCR-based methods are generally less affected by DNA quality and are more applicable to DNA extracted from various sources (fixed and fresh tissues). Ligation-mediated PCR techniques involve ligating an adaptor sequence onto a "representation" of DNA molecules, generated following enzymatic digestion, random shearing, or chemical cleavage. Adaptor-ligation PCR of randomly sheared genomic DNA (PRSG), described here, is based on ligation-mediated PCR and was designed to improve genome coverage. Rather than using enzymatically generated fragments, this method uses randomly fragmented DNA as the template. The process involves three steps: (1) the hydrodynamic shearing of genomic DNA to a 0.5-2-kb size range, (2) end filling and adaptor ligation, and (3) highstringency PCR for faithful replication of the resulting fragments.

\section{RELATED INFORMATION}

When implementing WGA in the laboratory, it is important to assess the entire experimental process closely, including sample collection, fixation, storage, and initial DNA extraction procedures, as all of these factors can affect DNA quality and thus have some bearing on the selection of the WGA technique. When using WGA, it is important first to validate the method selected and to become proficient in the technique before applying it to actual samples. Irrespective of the method selected, it is essential to establish that the results generated from the amplified DNA are indistinguishable from the results obtained from the original genomic DNA.

The DNA that can be amplified by PCR-based WGA includes DNA extracted from fixed, frozen, or archival tissue; whole blood; buccal swabs; single cells; sorted chromosomes; and laser-capture microdissected tissue (for microdissection of tissues embedded in paraffin, the sections must be deparaffinized prior to microdissection). Genomic DNA may be extracted using a variety of commercially available methods such as the QIAmp DNA mini-kit (QIAGEN). Fixation of tissues can introduce sequence variations and reduce overall DNA quality. When studying such tissues, prior examination of the DNA by agarose gel electrophoresis will help determine the DNA quality. The amplified DNA produced is suitable for a range of downstream genetic assays and thus has the potential for use not only in academic research, but also in commercial, forensic, and diagnostic laboratories.

PRSG was first reported by Tanabe et al. (2003). An assessment of the genome reproducibility provided by PRSG showed a failure rate of PCR of $<1 \%$ when PRSG products were generated from highquality DNA. However, the PCR failure rate increased (ranged from $30 \%$ to $50 \%$ ) and was sample-dependent when poor-quality genomic DNA obtained from formalin-fixed, paraffin-embedded samples was tested. 
Protocols for Whole-Genome Amplification by Degenerate Oligonucleotide Primed PCR (DOP-PCR), Whole-Genome Amplification by Improved Primer Extension Preamplification PCR (I-PEP-PCR), Whole-Genome Amplification by Single-Cell Comparative Genomic Hybridization PCR (SCOMP), and GenomePlex Whole-Genome Amplification are also available in this issue of CSH Protocols.

\section{MATERIALS}

CAUTIONS AND RECIPES: Please see Appendices for appropriate handling of materials marked with $<$ ! $>$, and recipes for reagents marked with $<\mathbf{R}>$.

\section{Reagents}

Agarose (Sigma)

$<$ R $><$ ! $>$ Ammonium acetate $(7.5 \mathrm{M})$

ATP (10 mM; Invitrogen)

BAL31 nuclease $(4 \mathrm{U} / \mu \mathrm{L})$ and accompanying $2 \mathrm{X}$ reaction buffer (Fermentas)

DNA size marker (100-bp ladder; Invitrogen)

Ethanol

$<$ !>Ethidium bromide (10 mg/mL; Sigma)

Genomic DNA (up to $1 \mu \mathrm{g}$ )

Glycogen (20 $\mu \mathrm{g} / \mathrm{mL}$; Invitrogen)

$\mathrm{H}_{2} \mathrm{O}$ (nuclease-free; Promega)

$<$ ! >Isopropanol

Oligonucleotides:

Adaptor 1: 5'-AATTCGGCGGCCGCGGATCC-3' (100 $\mu \mathrm{M})$

Adaptor 2: 5'-GCCGCCGGCGCCTAGG-3' $(100 \mu \mathrm{M})$

ER-1 PCR primer: 5'-GGAATTCGGCGGCCGCGGATCC-3' (100 $\mu \mathrm{M})$

One-Phor-All Buffer Plus (GE Healthcare)

Orange loading dye (6X; Fermentas)

$<$ !>Phenol:chloroform

Platinum Taq DNA polymerase ( $5 \mathrm{U} / \mu \mathrm{L}$ ) and accompanying 10X PCR buffer (Invitrogen)

T4 DNA ligase ( $5 \mathrm{U} / \mu \mathrm{L}$ ) and accompanying $5 \mathrm{X}$ ligase buffer (Invitrogen)

T4 DNA polymerase $(5 \mathrm{U} / \mu \mathrm{L})$ and the accompanying $5 \mathrm{X}$ reaction buffer (Invitrogen)

$<\mathrm{R}>\mathrm{TBE}$ buffer ( $1 \mathrm{X}$ diluted from a $10 \mathrm{X}$ stock at $\mathrm{pH} 8$; may also be obtained from Sigma)

$<\mathrm{R}>$ TE buffer $(1 \mathrm{X} ; \mathrm{pH} 7.5)$

\section{Equipment}

Electrophoresis apparatus

Hydrodynamic shearing machine (e.g., HydroShear; GeneMachines)

The HydroShear machine uses a ruby with a $0.05-\mathrm{mm}$ diameter hole to shear the DNA, an approach specific to this piece of equipment. Alternative machines or methods that generate DNA fragments within the desired size range (0.5-2 kb) will likely yield comparable results.

\section{METHOD}

Prepare at least two individual WGA amplifications for each DNA to be studied.

\section{DNA Shearing}

If the genomic DNA is already degraded, such as that obtained from laser-capture microdissected tissues, the procedure can be started at Step 4.

1. Shear $1 \mu \mathrm{g}(200 \mu \mathrm{L})$ of high-molecular-weight genomic DNA using an automated hydrodynamic shearing machine, according to the supplier's instructions (Thorstenson et al. 1998). 
We used the HydroShear machine to randomly fragment the DNA solution $(200 \mu \mathrm{L})$ at appropriate flow rates (speed codes 4 or 5) for 20 iterations.

See Troubleshooting.

2. Purify the solution of randomly fragmented DNA using phenol:chloroform, as described in CSH Protocols article Purification of Nucleic Acids by Extraction with Phenol:Chloroform.

3. Add $1 \mathrm{~mL}$ of glycogen, 0.5 volumes of $7.5 \mathrm{M}$ ammonium acetate, and 2.5 volumes of $100 \%$ isopropanol to the sample and precipitate the DNA as described in CSH Protocols article Standard Ethanol Precipitation of DNA in Microcentrifuge Tubes. Dissolve the pellet in $10 \mu \mathrm{L}$ of TE buffer.

\section{BAL31 Treatment of DNA}

4. Mix $5 \mu \mathrm{L}(\sim 500 \mathrm{ng})$ of DNA solution from Step 3 with $50 \mu \mathrm{L}$ of BAL31 reaction buffer, and incubate for $5 \mathrm{~min}$ at $70^{\circ} \mathrm{C}$, followed by $5 \mathrm{~min}$ at $30^{\circ} \mathrm{C}$.

5. Add $1 \mu \mathrm{L}$ of BAL31 nuclease, and incubate for $1 \mathrm{~min}$ at $30^{\circ} \mathrm{C}$.

6. Purify the DNA fragments by phenol:chloroform extraction (see Purification of Nucleic Acids by Extraction with Phenol:Chloroform), and dissolve the pellet in $7 \mu \mathrm{L}$ of TE buffer.

\section{End-Filling}

7. Add $2 \mu \mathrm{L}$ of T4 DNA polymerase buffer to the DNA from Step 6. Incubate the solution for $5 \mathrm{~min}$ at $70^{\circ} \mathrm{C}$ and then for $5 \mathrm{~min}$ at $30^{\circ} \mathrm{C}$.

8. Add $1 \mu \mathrm{L}$ of T4 DNA polymerase and incubate for $5 \mathrm{~min}$ at $37^{\circ} \mathrm{C}$.

9. Purify the DNA fragments by phenol:chloroform extraction (see Purification of Nucleic Acids by Extraction with Phenol:Chloroform), and dissolve the pellet in $25 \mu \mathrm{L}$ of TE.

PRSG Ligation of Adaptors and PCR Amplification

10. Prepare adaptor complexes by combining the following reagents:
$0.5 \mu \mathrm{L}$
One-Phor-All Buffer Plus
$0.5 \mu \mathrm{L}$
Adaptor oligonucleotide 1
$0.5 \mu \mathrm{L}$ Adaptor oligonucleotide 2
Add nuclease-free $\mathrm{H}_{2} \mathrm{O}$ to a final reaction volume of $3 \mu \mathrm{L}$.

11. To form the adaptor complexes, incubate the sample using a step-down program on a thermal cycler going from $65^{\circ} \mathrm{C}$ to $15^{\circ} \mathrm{C}$, ramping at $1^{\circ} \mathrm{C} / \mathrm{min}$.

12. Ligate the adaptors to the DNA fragments:

i. Combine the following reagents:

$\begin{array}{ll}1 \mu \mathrm{L}(20 \mathrm{ng}) & \text { DNA solution from Step } 9 \\ 4 \mu \mathrm{L} & \text { T4 DNA ligase reaction buffer } \\ 1 \mu \mathrm{L} & \text { Pre-formed adaptors from Step } 11 \\ 1 \mu \mathrm{L} & \text { ATP } \\ 12 \mu \mathrm{L} & \text { Nuclease-free } \mathrm{H}_{2} \mathrm{O} \\ 1 \mu \mathrm{L} & \text { T4 DNA ligase }\end{array}$

ii. Incubate for $12 \mathrm{~h}$ at $16^{\circ} \mathrm{C}$.

13. Perform PCR amplification as follows:

i. Combine the following reagents:

$\begin{array}{ll}1 \mu \mathrm{L}(1 \mathrm{ng}) & \text { Adaptor-ligated DNA mixture from Step 12.ii } \\ 77 \mu \mathrm{L} & \text { Nuclease-free } \mathrm{H}_{2} \mathrm{O} \\ 10 \mu \mathrm{L} & 10 X \text { PCR buffer } \\ 1 \mu \mathrm{L} & \text { ER-1 primer }\end{array}$


$\begin{array}{ll}10 \mu \mathrm{L} & \text { dNTP mix } \\ 1 \mu \mathrm{L} & \text { Platinum Taq DNA polymerase }\end{array}$

ii. Carry out the following cycling program:

\begin{tabular}{lll} 
Number of cycles & Temperature & Time \\
\hline $15-20$ & $94^{\circ} \mathrm{C}$ & $1 \mathrm{~min}$ \\
& $72^{\circ} \mathrm{C}$ & $3 \mathrm{~min}$ \\
1 & $72^{\circ} \mathrm{C}$ & $10 \mathrm{~min}$
\end{tabular}

Some DNA fragments have a high GC content and may form a stable secondary structure, which often prevents $P C R$ amplification at a standard annealing temperature of $50^{\circ} \mathrm{C}-60^{\circ} \mathrm{C}$. However, by using an adaptor in conjunction with a high annealing temperature $\left(72^{\circ} \mathrm{C}\right)$, the amplification bias during PCR due to differences in template sequence composition can be minimized. This, in turn, allows better genome coverage.

14. Aliquot the sample into five separate tubes $(20 \mu \mathrm{L}$ each $)$ and add:

$\begin{array}{ll}58 \mu \mathrm{L} & \text { Nuclease-free } \mathrm{H}_{2} \mathrm{O} \\ 10 \mu \mathrm{L} & 10 X \text { PCR buffer } \\ 1 \mu \mathrm{L} & \text { ER-1 primer } \\ 10 \mu \mathrm{L} & \text { dNTP mix } \\ 1 \mu \mathrm{L} & \text { Platinum Taq DNA polymerase }\end{array}$

15. PCR-amplify each aliquot for an additional five to 10 cycles using the PCR cycling conditions given in Step 13.ii.

To obtain sufficient yields of DNA, using a high-cycle-number PCR is not recommended, because this may introduce sequence bias caused by mispriming and preferential amplification of shorter fragments. Split the first PCR five ways after the initial 15-20 cycles, and then perform an additional five to 10 cycles on each aliquot.

16. Purify the DNA fragments by phenol:chloroform extraction followed by isopropanol precipitation as described in Steps 2 and 3. Dissolve the DNA pellet in $100 \mu \mathrm{L}$ of TE buffer.

Other DNA purification kits may be a suitable substitute for phenol extraction.

17. Determine the size of the products as follows:

i. Mix $5 \mu \mathrm{L}$ of the reaction mix with $1 \mu \mathrm{L}$ of $6 \mathrm{X}$ orange loading dye solution.

ii. Resolve the aliquot by Agarose Gel Electrophoresis using a 1\% agarose gel containing 20 $\mu \mathrm{g}$ of ethidium bromide $(10 \mathrm{mg} / \mathrm{mL})$ per $100 \mathrm{~mL}$ of agarose, alongside a DNA size marker. The expected yield of products is $5-10 \mu \mathrm{g}$, ranging in size from 0.4 to $1.5 \mathrm{~kb}$.

See Troubleshooting.

\section{TROUBLESHOOTING}

Problem: Sample processing (i.e., DNA shearing) is inefficient.

[Step 1]

Solution: Of all the processes involved in PRSG, DNA shearing is the most time-consuming, and hence the processing of multiple samples is best carried out using an automated system. When performing automated hydrodynamic shearing with the HydroShear, avoid using samples containing $>5 \mu$ of DNA, insoluble DNA, or other contaminants, because the small hole in the ruby of the HydroShear is easily blocked. If using an alternative approach to the HydroShear, first perform the protocol using a DNA sample for which results are known.

Problem: There is amplification in the negative control.

[Step 17.ii]

Solution: Due to the manipulation of PCR products in all PCR-based WGA methods, the reactions can easily be contaminated. If negative controls produce a DNA smear, several steps can be tried to eliminate this:

- Repeat using fresh reagents.

- Use filtered tips to avoid introduction of contaminants via aerosol from the pipette. 
- Physically separate the areas in the laboratory where reactions are set up. Prepare and pipette the PCR mixture at one bench, and then add the DNA to the reaction in a different location in the laboratory. Also, use different pipettes for reaction preparation and pipetting of DNA.

- Aliquot all reaction constituents; if an aliquot becomes contaminated, only that aliquot will be lost and not the entire stock.

Problem: Unpredictable amplification is observed.

[Step 17.ii]

Solution: A positive control (such as starting with $50 \mathrm{ng}$ of good-quality genomic DNA) can be used to ensure that the reaction is working optimally. In addition:

- Store small aliquots of dNTPs and oligonucleotides, because repeated freeze/thaw cycles of a single stock can affect the integrity of these reagents and thereby affect the efficiency of WGA.

- The starting concentration of DNA is crucial. Best results are obtained when starting with $10 \mathrm{ng}$ (or greater) of DNA extracted from fresh tissue/blood or $100 \mathrm{ng}$ of DNA extracted from fixed tissue. Lower amounts of DNA ( $<10 \mathrm{ng}$ from fresh tissue or $<100 \mathrm{ng}$ from fixed tissue) will generate amplification products, but results obtained in downstream applications may not be faithful to the result that would have been obtained from nonamplified DNA.

- In ligation-mediated PCR techniques, lack of amplification or poor amplification may be due to problems with either the DNA or the adaptor ligation. For the former, always include a positive control of 10-100 ng of good-quality, high-molecular-weight DNA. If this sample produces good results, the assay problems are a product of the DNA sample under investigation. However, if the positive control does not amplify, it suggests a problem with the reaction constituents or the thermal cycling. In such cases, use fresh aliquots of reagents, and repeat the experiment. If the problem still persists, it may be necessary to order fresh reagents.

Problem: The amplification smear contains smaller DNA fragments than expected.

[Step 17.ii]

Solution: The efficiency of amplification is dependent on the quality of the starting DNA, and the size of the amplification products is also template-dependent. Tissue fixation causes degradation of template DNA within the sample. If the template is degraded, as is DNA from formalin-fixed, paraffin-embedded material, the smear will be smaller in size. Unfortunately, there is no way of improving this; thus care must be taken when using such products for downstream applications, because there may be more bias in these samples. Although PCR-based WGA is tolerant to mild or moderate DNA degradation and will amplify DNA with an average length of $\sim 200 \mathrm{bp}$, in this case it is essential to use increased quantities of starting DNA (100 ng) to guarantee a satisfactory yield of final product. Moderate to severe degradation will reduce WGA efficiency and subsequently decrease the quality of results obtained in downstream applications.

Problem: There is insufficient DNA for downstream reactions.

[Step 17.ii]

Solution: Combine at least two individual WGA amplifications for each DNA to be studied, as this has produced better results in downstream experiments.

Problem: Unpredictable results are obtained from downstream applications.

Solution: Successful PCR-based WGA and successful downstream results depend on the quality of starting DNA. For instance, if there is ineffective PCR amplification of a specific control gene with nonamplified DNA, negative results after WGA are to be expected. If using laser-capture microdissected material, perform a standard control PCR and a PCR using DNA from nonlaser-capture microdissected tissue prior to WGA. In some cases, it may be necessary to try different amounts of amplified DNA in downstream PCR amplification procedures, for example, 12, 25, 50, and $100 \mathrm{ng}$.

\section{DISCUSSION}

PRSG has been used successfully for single-nucleotide polymorphism (SNP) analysis, microsatellite analysis, Southern blotting, and array comparative genomic hybridization (CGH). In an analysis of 307 microsatellites distributed throughout the genome, $84 \%$ were reproducibly amplified in PRSG DNA, 
and of these, $99 \%$ showed a consistent pattern between the PRSG product and the original genomic DNA (Tanabe et al. 2003). Array CGH experiments using an esophageal cancer cell line, TE6, showed $>90 \%$ concordance of the fluorescence ratios between the PRSG-amplified and matched nonamplified DNA (Tanabe et al. 2003).

\section{REFERENCES}

Tanabe, C., Aoyagi, K., Sakiyama, T., Kohno, T., Yanagitani N. Akimoto, S., Sakamoto, M., Sakamoto, H., Yokota, J., and Ohki, M. 2003. Evaluation of a whole-genome amplification method based on adaptor-ligation PCR of randomly sheared genomic
DNA. Genes Chromosomes Cancer 38: 168-176.

Thorstenson, Y.R., Hunicke-Smith, S.P., Oefner, P.J., and Davis, R.W. 1998. An automated hydrodynamic process for controlled, unbiased DNA shearing. Genome Res. 8: 848-855. 


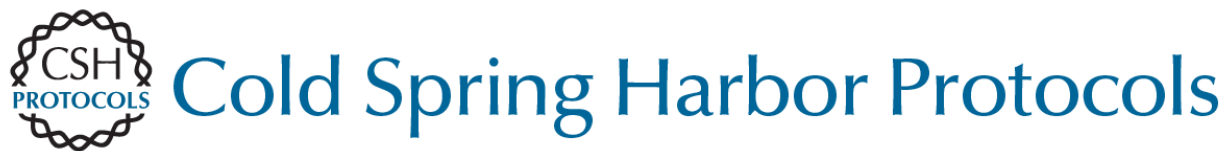

\section{Whole-Genome Amplification by Adaptor-Ligation PCR of Randomly Sheared Genomic DNA (PRSG)}

Nona Arneson, Simon Hughes, Richard Houlston and Susan Done

Cold Spring Harb Protoc; doi: 10.1101/pdb.prot4922

\begin{tabular}{rc}
$\begin{aligned} \text { Email Alerting } \\
\text { Service }\end{aligned}$ & Receive free email alerts when new articles cite this article - click here. \\
\hline $\begin{array}{c}\text { Subject } \\
\text { Categories }\end{array}$ & Browse articles on similar topics from Cold Spring Harbor Protocols. \\
& Amplification of DNA by PCR (85 articles) \\
& Bioinformatics/Genomics, general (192 articles) \\
& DNA Sequencing (96 articles) \\
& Genetic Variation (86 articles) \\
& Genetics, general (374 articles) \\
& Genome Analysis (191 articles) \\
& Genomic DNA (135 articles) \\
& Genomic Libraries (66 articles) \\
& Libraries (147 articles) \\
& Libraries, general (113 articles) \\
& Molecular Biology, general (1293 articles) \\
& Polymerase Chain Reaction (PCR) (139 articles) \\
& Polymerase Chain Reaction (PCR), general (184 articles) \\
\hline
\end{tabular}

